\title{
日本病理剖検輯報に基づく舌癌剖検症例の統計的検討（第 $\mathbb{V}$ 報）
}

\author{
佐 藤 方信 ·藤 井佳 人 · 佐島三重子 · 大津 匡 志
}

\section{A statistical study of autopsy cases of tongue cancer collected from the Annals of Pathological Autopsy Cases in Japan (Part IV)}

\author{
Masanobu $\mathrm{S}_{\Lambda \mathrm{TOH}} \cdot$ Yoshihito FuJII $\cdot$ Mieko Sashima $\cdot$ Tadashi Otsu
}

\begin{abstract}
To study malignant neoplasms of the tongue in Japan, we statistically analyzed autopsy cases of malignant neoplasms of the tongue reported in the Annals of Pathological Autopsy Cases in Japan during a 5 -year period (1987-1991).
\end{abstract}

The following results were obtained.

1. A total number of 473 cases ( 337 males, 136 females) of malignant neoplasms of the tongue were reported.

2. Among patients who died of malignant neoplasms of the tongue, the autopsy rate was $14.5 \%$.

3. Malignant neoplasms of the tongue were found most frequently in the seventh decade $(29.6 \%)$, followed by the eighth decade $(24.7 \%)$ and sixth decade $(20.9 \%)$.

4. Histologically $96.6 \%$ of malignant neoplasms of the tongue were squamous cell carcinoma.

5. Squamous cell carcinoma most frequently arose in the lateral border of the tongue $(53.5 \%)$, followed by the root of the tongue $(28.9 \%)$.

6 . With respect to organ metastasis, the lung was the most common site, followed by the liver, bone, skin and thyroid. With regard to the lymph nodes, the cervical nodes were the most frequently invaded, followed by the pulmonary hilar, laryngeal, paraesophageal and paratracheal nodes.

7. Multiple primary cancers, affecting both the tongue and other organs, were found in 123 cases (96 males, 27 females).

8. The most common cause of death not associated with malignant neoplasms of the tongue was pulmonary infection.

Key words: tongue cancer (辞澏), autopsy case (剖検例), statistical report (統計的検討)

緒 言

人に動態統計 1-12)によるとわが国における舌の悪 性新生物による死し者数は 1981 年に 549 例であった

岩和原科大学㐘学部小腔病理学講座

(主任: : 佐藤方信教授)

Department of Oral Pathology, School of Dentistry, Iwate Medical University (Chief: Prof. Masanobu Satoh )

受付议成 7 年 5 月18日
が (表 1)，その後ほぼ逐年的に増加し，1991 年に 701 例となり，1992 年度には 796 例と著しい増加をみせて いる。著者らはこれまでにわが国における舌癌症例の 実態の解明を目的に口本病理剖検輯報より収集した症 例を種々の観就から検討し, その結果を報告してき た13-15). 今回，われわれは最近の 5 年間に本邦で剖 検された舌の悪性新生物症例を集計し, 種々の観点か ら検傠したので若干の考察を加えてその結果を報告する. 
表 1 我国の舌の悪性新生物による死亡者数

\begin{tabular}{cccc}
\hline \multirow{2}{*}{ 年 度 } & \multicolumn{3}{c}{ 死亡数* $^{*}$} \\
\cline { 2 - 4 } & 男 & 女 & 合計 \\
\hline 1981 & 359 & 190 & 549 \\
1982 & 401 & 183 & 584 \\
1983 & 377 & 198 & 575 \\
1984 & 385 & 214 & 599 \\
1985 & 375 & 214 & 589 \\
1986 & 393 & 226 & 619 \\
1987 & 401 & 194 & 595 \\
1988 & 436 & 203 & 639 \\
1989 & 406 & 233 & 639 \\
1990 & 440 & 255 & 695 \\
1991 & 464 & 237 & 701 \\
1992 & 515 & 281 & 796 \\
\hline
\end{tabular}

*人口動態統計 (下巻) による.

$$
\text { 材 料. 方 法 }
$$

日本病理剖検輯報（以下輯報と略）第 30 輯 ${ }^{16)}, 31$ 輯1 7)，32 輯18)，33 輯19) および 34 輯20) より，わが国 において 1987 年から 1991 年の 5 年間に病理解剖され た舌癌症例を収集し，これを基に種々の観点から集計 し，検討を加えた。

転移の部位別症例数は年度別に輯報に記載されてい る症例数を 5 年間について集計したものである.

\section{成}

\section{1. 剖検症例数と剖検率の年度別推移（表 2 )}

わが国において過去 5 年間 $(1987,1988,1989,1990$,

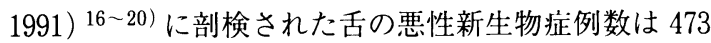
例である。この間, 最も症例が多かったのは 1988 年で, 以後は逐年的に減少していた。このような減少傾向は 剖検症例総数, 悪性新生物総剖検数にもみられており, 特に舌の悪性新生物剖検症例に限った傾向ではなかった。

人口動態統計によると, わが国における舌の悪性新 生物による死亡者数はこの 5 年間で逐年的な増加の傾 向が見られた ${ }^{7}$-11).この期間における舌の悪性新生

表 2 舌の悪性新生物剖検症例数の年度別推移

\begin{tabular}{|c|c|c|c|c|c|c|c|c|c|c|c|}
\hline \multirow[t]{2}{*}{ 年度 } & 性 & \multicolumn{2}{|c|}{$\begin{array}{l}\text { 剖検症例 } \\
\text { 総数* }\end{array}$} & \multicolumn{2}{|c|}{$\begin{array}{l}\text { 悪性新生物 } \\
\text { 総剖検数* }\end{array}$} & \multicolumn{4}{|c|}{$\begin{array}{c}\text { 舌の悪性新生物 } \\
\text { 死亡数 }(\mathrm{M})^{* * *} \text { 剖検数 }(\mathrm{T})\end{array}$} & \multicolumn{2}{|c|}{$\begin{array}{c}\text { 剖検率 (\%) } \\
\mathrm{T} / \mathrm{M} \times 100\end{array}$} \\
\hline & 男 & 24526 & & 15244 & & 401 & & 68 & & 17.0 & \\
\hline \multirow[t]{3}{*}{1987} & 女 & 14785 & 39399 & 8072 & 23332 & 194 & 595 & 24 & 92 & 12.4 & 15.5 \\
\hline & 不明 & 88 & & 16 & & 0 & & 0 & & 0 & \\
\hline & 男 & 23511 & & 15132 & & 436 & & 74 & & 17.0 & \\
\hline \multirow[t]{3}{*}{1988} & 女 & 13750 & 37287 & 8081 & 23228 & 203 & 639 & 30 & 104 & 14.8 & 16.3 \\
\hline & 不明 & 26 & & 15 & & 0 & & 0 & & 0 & \\
\hline & 男 & 22976 & & 14969 & & 406 & & 68 & & 16.7 & \\
\hline \multirow[t]{3}{*}{1989} & 女 & 13527 & 36524 & 7951 & 22931 & 233 & 639 & 32 & 100 & 13.7 & 15.6 \\
\hline & 不明 & 21 & & 11 & & 0 & & 0 & & 0 & \\
\hline & 男 & 23046 & & 14609 & & 440 & & 59 & & 13.4 & \\
\hline \multirow[t]{3}{*}{1990} & 女 & 13323 & 36382 & 7691 & 22307 & 255 & 695 & 31. & 90 & 12.2 & 12.9 \\
\hline & 不明 & 13 & & 7 & & 0 & & 0 & & 0 & \\
\hline & 男 & 21978 & & 14186 & & 464 & & 68 & & 14.7 & \\
\hline \multirow[t]{3}{*}{1991} & 女 & 12738 & 34721 & 7416 & 21606 & 237 & 701 & 19 & 87 & 8.0 & 12.4 \\
\hline & 不明 & 5 & & 4 & & 0 & & 0 & & 0 & \\
\hline & 男 & 116037 & & 74140 & & 2147 & & 337 & & 15.7 & \\
\hline \multirow[t]{2}{*}{ 合計 } & 女 & 68123 & 184313 & 39211 & 113404 & 1122 & 3269 & 136 & 473 & 12.1 & 14.5 \\
\hline & 不明 & 153 & & 53 & & 0 & & 0 & & 0 & \\
\hline
\end{tabular}

* 新生児, 死産児および検討中の症例は除く. ${ }^{* *}$ 人口動態統計 (厚生省)による. 
表 3 舌の悪性新生物剖検症例の年代別症例数

\begin{tabular}{|c|c|c|c|c|c|c|c|c|c|c|c|c|}
\hline \multirow{2}{*}{ 年度 } & \multirow{2}{*}{ 性 } & \multicolumn{10}{|c|}{ 年 代 （歳） } & \multirow{2}{*}{ 合計 } \\
\hline & & $0-9$ & $10-19$ & $20-29$ & $30-39$ & $40-49$ & $50-59$ & $60-69$ & $70-79$ & $80-89$ & $90-99$ & \\
\hline \multirow{4}{*}{1987} & 男 & 0 & 0 & 0 & 3 & 5 & 18 & 25 & 14 & 3 & 0 & 68 \\
\hline & 女 & 0 & 0 & 2 & 0 & 1 & 6 & 4 & 5 & 6 & 0 & 24 \\
\hline & 不明 & 0 & 0 & 0 & 0 & 0 & 0 & 0 & 0 & 0 & 0 & 0 \\
\hline & 計 & 0 & 0 & 2 & 3 & 6 & 24 & 29 & 19. & 9 & 0 & 92 \\
\hline \multirow{4}{*}{1988} & 男 & 0 & 0 & 0 & 1 & 11 & 10 & 30 & 18 & 4 & 0 & 74 \\
\hline & 女 & 0 & 0 & 0 & 0 & 4 & 6 & 5 & 7 & 8 & 0 & 30 \\
\hline & 不明 & 0 & 0 & 0 & 0 & 0 & 0 & 0 & 0 & 0 & 0 & 0 \\
\hline & 計 & 0 & 0 & 0 & 1 & 15 & 16 & 35 & 25 & 12 & 0 & 104 \\
\hline \multirow{4}{*}{1989} & 男 & 0 & 0 & 0 & 2 & 14 & 12 & 18 & 19 & 2 & 1 & 68 \\
\hline & 女 & 0 & 0 & 0 & 4 & 2 & 8 & 4 & 8 & 2 & 4 & 32 \\
\hline & 不明 & 0 & 0 & 0 & 0 & 0 & 0 & 0 & 0 & 0 & 0 & 0 \\
\hline & 計 & 0 & 0 & 0 & 6 & 16 & 20 & 22 & 27 & 4 & 5 & 100 \\
\hline \multirow{4}{*}{1990} & 男 & 0 & 0 & 1 & 1 & 5 & 9 & 22 & 15 & 6 & 0 & 59 \\
\hline & 女 & 0 & 0 & 0 & 1 & 3 & 6 & 6 & 12 & 3 & 0 & 31 \\
\hline & 不明 & 0 & 0 & 0 & 0 & 0 & 0 & 0 & 0 & 0 & 0 & 0 \\
\hline & 計 & 0 & 0 & 1 & 2 & 8 & 15 & 28 & 27 & 9 & 0 & 90 \\
\hline \multirow{4}{*}{1991} & 男 & 0 & 0 & 0 & 0 & 5 & 21 & 19 & 17 & 5 & 1 & 68 \\
\hline & 女 & 0 & 0 & 0 & 0 & 4 & 3 & 7 & 2 & 1 & 2 & 19 \\
\hline & 不明 & 0 & 0 & 0 & 0 & 0 & 0 & 0 & 0 & 0 & 0 & 0 \\
\hline & 計 & 0 & 0 & 0 & 0 & 9 & 24 & 26 & 19 & 6 & 3 & 87 \\
\hline \multirow{4}{*}{ 合計 } & 男 & 0 & 0 & 1 & 7 & 40 & 70 & 114 & 83 & 20 & 2 & 337 \\
\hline & 女 & 0 & 0 & 2 & 5 & 14 & 29 & 26 & 34 & 20 & 6 & 136 \\
\hline & 不明 & 0 & 0 & 0 & 0 & 0 & 0 & 0 & 0 & 0 & 0 & 0 \\
\hline & $\begin{array}{c}\text { 計 } \\
\text { (\%) }\end{array}$ & $\begin{array}{c}0 \\
(0)\end{array}$ & $\begin{array}{c}0 \\
(0)\end{array}$ & $\begin{array}{c}3 \\
(0.6)\end{array}$ & $\begin{array}{c}12 \\
(2.5)\end{array}$ & $\begin{array}{c}54 \\
(11.4)\end{array}$ & $\begin{array}{c}99 \\
(20.9)\end{array}$ & $\begin{array}{c}140 \\
(29.6)\end{array}$ & $\begin{array}{c}117 \\
(24.7)\end{array}$ & $\begin{array}{c}40 \\
(8.6)\end{array}$ & $\begin{array}{c}8 \\
(1.7)\end{array}$ & 473 \\
\hline
\end{tabular}

物による死亡者数に対する各年度の単純計算した剖検 率は 1988 年度が $16.3 \%$ で最も高く, 以後年々低くな ク，1991 年度は $12.4 \%$ になっていた。男女別の剖検率 は各年度において男性将例が高かった。

\section{2 . 年代別症例数（表 3 ）と年度別平均年齢}

死亡数の最も多い年代は年度により違いが見られた が，5年間の集計でみると， 60 歳代が 140 例 $(29.6 \%)$ と最も多く, 70 歳代 (117 例), 50 歳代 (99 例), 40 歳 代 (54 例), 80 歳代 (40 例) と続き, 40 歳未満と 90 歳 以上の怔例は少なく, 20 歳未満の怔例はみられなかっ た。

各年度別にみた剖検症例の平均年齢は 1987 年が $63.2 \pm 12.6$ 歳 (男 $63.0 \pm 11.2$, 女 $65.1 \pm 16.1$ ), 1988 年

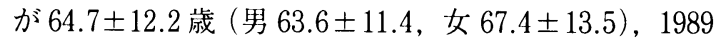

年が $62.4 \pm 14.2$ 歳（男 $61.5 \pm 12.5$, 女 $64.2 \pm 17.1$ ), 1990 年が $64.8 \pm 12.4$ 歳 (男 $64.8 \pm 12.2$, 女 $64.9 \pm 12.9$ ), 1991 年が $64.5 \pm 12.0$ 歳 (男 $64.6 \pm 11.1$, 女 $64.1 \pm 14.6$ ) であり，この 5 年間において逐年的には特別の傾向は みられなかった。

\section{3 . 舌癌の発生部位 (表 4 )}

舌癌の発生部位の集計は扁平上皮癌についてのみ行つ た. 扁平上皮癌と記載されているが部位の記載がない 症例が 348 例と非常に多く, 部位不明と記載されてい たのが 10 例であった。発生部位が記載されている症 例について集計してみると, 舌 (側) 縁が 61 例 $(53.5$ \%) で, その半数を占め, 以下, 舌根（後）部が 33 例 $(28.9 \%)$, 舌下面が 5 例 $(4.4 \%)$ であり, 舌尖（前）部 は 3 例, 舌背部は 1 例と少なかった. 
表 4 舌癌剖検症例の発生部位別症例数

\begin{tabular}{|c|c|c|c|c|c|c|c|c|c|c|}
\hline \multirow{2}{*}{ 部位 } & \multicolumn{3}{|c|}{ 男 } & \multicolumn{3}{|c|}{ 女 } & \multicolumn{3}{|c|}{ 合 計 } & \multirow[b]{2}{*}{ 計 (\%) } \\
\hline & 左 & 右 & 不記载 & 左 & 右 & 不記載 & 左 & 右 & 不䛉载 & \\
\hline 舌尖 (前) & 0 & 1 & 0 & 1 & 0 & 1 & 1 & 1 & 1 & $3(2.6)$ \\
\hline 舌 (側) 縁 & 20 & 22 & 0 & 8 & 10 & 1 & 28 & 32 & 1 & $61(53.5)$ \\
\hline 舌根 (後) & 4 & 6 & 18 & 0 & 0 & 5 & 4 & 6 & 23 & $33(28.9)$ \\
\hline 舌下面 & 0 & 0 & 4 & 0 & 0 & 1 & 0 & 0 & 5 & $5(4.4)$ \\
\hline 舌 背 & 0 & 0 & 0 & 0 & 1 & 0 & 0 & 1 & 0 & $1(0.9)$ \\
\hline 央 & 0 & 0 & 1 & 0 & 0 & 0 & 0 & 0 & 1 & $1(0.9)$ \\
\hline 明 & 3 & 3 & 0 & 1 & 3 & 0 & 4 & 6 & 0 & $10(8.8)$ \\
\hline 不記 載 & 1 & 8 & 234 & 5 & 4 & 90 & 12 & 12 & 324 & 348 \\
\hline 合 計* & & 70 & 257 & 15 & 18 & 98 & 49 & 58 & 355 & 462 \\
\hline
\end{tabular}

表 6 舌の悪性新生:物との多重癌症例数

\begin{tabular}{cccc}
\hline 年度 & 男 & 女 & 㐱計 $\left(\%^{*}\right)$ \\
\hline 1987 & 17 & 2 & $19(20.7)$ \\
1988 & 20 & 8 & $28(26.9)$ \\
1989 & 22 & 4 & $26(26.0)$ \\
1990 & 20 & 10 & $30(33.3)$ \\
1991 & 17 & 3 & $20(23.0)$ \\
\hline 合計 & 96 & 27 & $123(26.0)$ \\
\hline
\end{tabular}

*多重癌症例数の割令

*扁平上皮癌のみ集計

表 7 :重癌症例の組み命わ甘臟器別症例数

表 5 舌の悪性新生物剖検例の組織型別症例数

\begin{tabular}{|c|c|c|c|}
\hline 組 織 像 & 男 & 女 & 合計 \\
\hline 扁平上皮癌 & 215 & 92 & 307 \\
\hline 高分化型扁平上皮癌 & 42 & 17 & 59 \\
\hline 中分化型扁平上皮癌 & 20 & 11 & 31 \\
\hline 低分化型扁平上皮癌 & 5 & 2 & 7 \\
\hline 角化型扁平上皮癌 & 11 & 1 & 12 \\
\hline 分化型扁平上皮癌 & 2 & 0 & 2 \\
\hline 有棘細胞癌 & 1 & 0 & 1 \\
\hline 腺扁平上皮癌 & 4 & 0 & 4 \\
\hline 中分化型腺癌 & 1 & 0 & 1 \\
\hline 未分化癌 & 0 & 1 & 1 \\
\hline 悪性リンパ腫 & 5 & 1 & 6 \\
\hline 悪性黑色腫 & 0 & 2 & 2 \\
\hline 粘表皮癌 & 1 & 1 & 2 \\
\hline 腺様囊胞癌 & 1 & 1 & 2 \\
\hline 悪性混合腫 & 1 & 0 & 1 \\
\hline 不記載 & 28 & 7 & 35 \\
\hline 合計 & 337 & 136 & 473 \\
\hline
\end{tabular}

発生側の記載されていない355 例を除いて舌癌の発 生側をまとめてみると, 左側が 49 例 $(45.8 \%)$, 有側 が 58 例 $(54.2 \%)$ であった。

\section{4 . 組織型別症例数（表 5 ）と平均年齢}

組織型別症例数の集計にあたつては輯報に記載され ている組織診断名をそのまま集計したが, 組織型の記 載されていない怔例が 35 例と多かった。また, 組織 学的分化度を記載せず単に扁平上皮癌とのみ記載され

\begin{tabular}{|c|c|c|c|}
\hline \multirow{2}{*}{ 組 命 せ } & \multicolumn{3}{|c|}{ 症: 例 数 } \\
\hline & 男 & 女 & 尌 \\
\hline 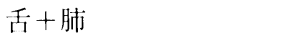 & 17 & 3 & 20 \\
\hline 舌十胃（含早期癌） & 13 & 6 & 19 \\
\hline 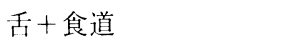 & 13 & 2 & 15 \\
\hline 舌十前立腺（含潜在癌） & 6 & 0 & 6 \\
\hline 舌十甲状腺（含潜在癌） & 1 & 4 & 5 \\
\hline 舌＋大腸 & 5 & 0 & 5 \\
\hline 系十歯肉 & 0 & 4 & 4 \\
\hline 舌十肝 & 4 & 0 & 4 \\
\hline 刑＋呐頭 & 3 & 0 & 3 \\
\hline 舌十喉頭 & 3 & 0 & 3 \\
\hline 舌十乳腺 & 1 & 2 & 3 \\
\hline 舌＋膵 & 1 & 1 & 2 \\
\hline 高十腎 & 2 & () & 2 \\
\hline 舌+膀胱 & 2 & 0 & 2 \\
\hline 舌+十自病 & 2 & 0 & 2 \\
\hline 舌十问腸カルチノイド & 1 & 0 & 1 \\
\hline 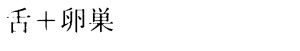 & 0 & 1 & 1 \\
\hline 舌＋多発性骨髄腫 & 1 & 0 & 1 \\
\hline 畐の悪性リンパ腫十肺j & 1 & 0 & 1 \\
\hline 全 部 & 76 & 23 & 99 \\
\hline
\end{tabular}

た怔例が 307 例と多かった。組織型および組織学的分 化度が付記されていた将例についてのみ集战してみる と（表 5 ），高分化型雇中!皮澏が 59 例で最も多く，

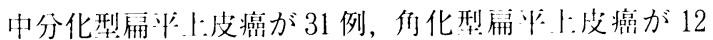

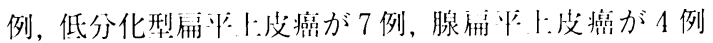


表 8 多重癌症例の組み合わせ臓器別症例数

\begin{tabular}{|c|c|c|c|}
\hline \multirow{2}{*}{ 組 命せ } & \multicolumn{2}{|c|}{ 症 例 } & 数 \\
\hline & 男 & 女 & 計 \\
\hline \multicolumn{4}{|l|}{ 三重癌 } \\
\hline 舌十食道十肺 & 2 & 0 & 2 \\
\hline 舌＋食道十咑頭 & 1 & 0 & 1 \\
\hline 话十食道十喉頭 & 1 & 0 & 1 \\
\hline 芼十食道十肺 & 1 & 0 & 1 \\
\hline 舌十肺＋胃 & 1 & 1 & 2 \\
\hline 舌十柬肉十食道 & 1 & 0 & 1 \\
\hline 舌十川1低+咑頭 & 1 & 0 & 1 \\
\hline 舌＋胃＋食道 & 1 & 0 & 1 \\
\hline 考＋狊＋AML & 1 & 0 & 1 \\
\hline 舌十出十前泣腺 & 1 & 0 & 1 \\
\hline 舌十帱十柙状腺 & 1 & 0 & 1 \\
\hline 舌十肺 +11腔 & 1 & 0 & 1 \\
\hline 舌十肺＋甲状腺 & 1 & 0 & 1 \\
\hline 舌＋肺＋汥䖉 & 0 & 1 & 1 \\
\hline 舌＋肺＋乳腺 & 0 & 1 & 1 \\
\hline 舌＋喉頭＋皮䖉 & 1 & 0 & 1 \\
\hline 舌＋肝＋膀胱 & 1 & 0 & 1 \\
\hline 舌十直腸＋前立腺 & 1 & 0 & 1 \\
\hline 舌+腎+子宮 & 0 & 1 & 1 \\
\hline 舌＋前立腺＋MM & 1 & 0 & 1 \\
\hline 合計 & 18 & 4 & 22 \\
\hline \multicolumn{4}{|l|}{ 四重癌 } \\
\hline 舌 + 肺十直腸十前立腺 & 1 & 0 & 1 \\
\hline 舌＋肝＋直腸＋ML & 1 & 0 & 1 \\
\hline 合計 & 2 & 0 & 2 \\
\hline
\end{tabular}

ML: 悪性リンパ腫, MM: 多発性骨髄腫

であった。その他，蚛性リンパ腫が 6 例で，恶性黑色 腫, 粘表皮澏, 腺様囊胞癌がそれぞれ 2 例などであった。 組織学的分化度別（多重癌怔例を除く）の平均年齢 (症例数) では，高分化型扁平上.波癌症例が $61.2 \pm 13.4$ 歳 (52), 中分化型扁平上波癌症例が $61.6 \pm 9.0$ 歳 (28), 低分化型扁平上皮癌泟例が $66.0 \pm 14.8$ 歳（5）であっ た．組織学的分化度と剖検怔例の年齢との間には有意 の関連はみられなかった（F 検定）。

\section{5 . 多重癌症例数 (表 6 ) と重複臓器 (表 7,8 )}

舌の悪性新生物に他臟器の悪性新生物を重複する多 重癌症例がこの 5 年間で 123 例認められた（表 6 ）。多 重癌证例の少なかったのは1987 年の 19 例（20.7\%）,
表 9 舌癌剖検症例の臓器別転移症例数

\begin{tabular}{|c|c|c|c|}
\hline 臓 器 & 症例数 & 臓 器 & 症例数 \\
\hline 口唇 & 6 & 縦隔·胸腺 & 18 \\
\hline 舌 & 32 & 他の呼吸器 & 2 \\
\hline 大唾液腺 & 16 & 皮膚·皮下組織 & 76 \\
\hline 歯肉 & 5 & 腎 & 64 \\
\hline 他の口腔 & 42 & 腎孟 & 2 \\
\hline 咽頭 & 50 & 眼窩 & 1 \\
\hline 食道 & 26 & 頭蓋底·頭蓋骨 & 8 \\
\hline 胃 & 6 & 脳·脳膜 · 頭蓋内 & 7 \\
\hline 小腸 - 十二指腸 & 5 & 脊髄 · 脊髄膜 & 4 \\
\hline 肝·肝内胆管 & 88 & 甲状腺 & 72 \\
\hline 結腸 · 盲腸 - 直腸 & 5 & 副腎 & 55 \\
\hline 胆囊 · 外胆管 & 4 & 下垂体 & 1 \\
\hline 膵 & 11 & 卵巣 & 4 \\
\hline 横隔膜 ～～～～～～～ & 37 & 脾臓 & 23 \\
\hline 腹, 腸間膜 - 大網 & 15 & 骨 · 骨髄 · 椎骨 & 87 \\
\hline 腹壁 & 1 & 大血管 & 6 \\
\hline 鼻· 副鼻 & 1 & 心臓 & 49 \\
\hline 叫頭 & 35 & 心外膜 & 24 \\
\hline 肺·気管（支） & 225 & 軟部組織 ·骨格筋 & 54 \\
\hline 肋膜・胸壁 & 75 & その他 ～～～～～ & 14 \\
\hline
\end{tabular}

表10 舌癌剖検症例のリンパ節転移の部位別症例数

\begin{tabular}{|c|c|}
\hline 部位 & 症 例 数 \\
\hline 頭部 & 6 \\
\hline 頸部 & 133 \\
\hline 鎖骨 (含Virchow) & 35 \\
\hline 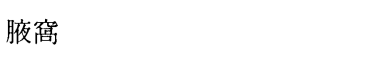 & 12 \\
\hline 喉頭 ·食道 ·気管周囲 & 62 \\
\hline 縦隔・静脈角 & 39 \\
\hline 肺・肺門 & 91 \\
\hline 胸大動脈周囲 & 10 \\
\hline 腹大動脈周囲 - 後腹膜 - 腹腔 & 25 \\
\hline 大動脈周囲 & 14 \\
\hline 肝門 & 7 \\
\hline 胃周囲 & 7 \\
\hline 膵・脾周囲 & 11 \\
\hline 腸間膜 & 4 \\
\hline 骨盤内・腸骨 & 1 \\
\hline そけい & 2 \\
\hline その他 & 10 \\
\hline
\end{tabular}


表11 舌悪性新生物剖検症例における死因となった副病変

\begin{tabular}{|c|c|c|c|c|c|c|c|}
\hline \multirow{2}{*}{ 副 病 変* } & \multicolumn{3}{|c|}{ 症例数 } & \multirow{2}{*}{ 副 病 変* } & \multicolumn{3}{|c|}{ 症例数 } \\
\hline & 男 & 女 & 計 & & 男 & 女 & 計 \\
\hline 気管支肺炎 & 36 & 10 & 46 & 窒息 & 0 & 1 & 1 \\
\hline 気管支肺炎＋肺膿瘍 & 1 & 3 & 4 & 敗血症 & 5 & 3 & 8 \\
\hline 気管支肺炎＋肺動脈㾞（大量出血） & 1 & 0 & 1 & 敗血症十気管支肺炎十微小膿瘍 & 1 & 0 & 1 \\
\hline 気管支肺炎+胸水 & 1 & 0 & 1 & 再生不良性筫血, 敗血症 & 1 & 0 & 1 \\
\hline 気管支肺炎＋肺の罍血水腫 & 1 & 1 & 2 & 敗血症性緑膿菌肺炎 & 1 & 0 & 1 \\
\hline 気管支肺炎＋間質性肺炎 & 1 & 0 & 1 & カンジダによる敗血症 & 1 & 0 & 1 \\
\hline 気管支肺炎十両肺線維症 & 1 & 1 & 2 & 全身性真菌感染 & 1 & 1 & 2 \\
\hline 肺炎 & 3 & 1 & 4 & 敗血症性ショック（黄色ブドウ球菌） & 1 & 0 & 1 \\
\hline 大葉性肺炎 & 1 & 0 & 1 & 穿孔性十二指腸潰瘍 & 1 & 0 & 1 \\
\hline 化膿性肺炎 & 4 & 2 & 6 & 肝硬変 & 2 & 1 & 3 \\
\hline 両肺化膿症＋左化膿性胸膜炎 & 0 & 1 & 1 & DIC & 2 & 2 & 4 \\
\hline 肺膿瘍 & 1 & 1 & 2 & 舌縫合部出血 & 1 & 0 & 1 \\
\hline 壊疽性肺炎 & 1 & 0 & 1 & 舌癌局所再発部大量出血 & 1 & 0 & 1 \\
\hline 肺化膿症＋肺真菌症＋食道気管瘻 & 1 & 0 & 1 & 腫瘍浸潤による総頸動脈破裂 & 3 & 0 & 3 \\
\hline 壊疽性肺炎+アスペルギルス症＋気胸 & 1 & 0 & 1 & 頸動脈破裂 & 1 & 1 & 2 \\
\hline 肺カンジダ症 & 1 & 0 & 1 & 左総頸動脈瘤 & 0 & 1 & 1 \\
\hline 間質性肺炎 & 3 & 0 & 3 & 左頸部血管破綻性出血 & 0 & 1 & 1 \\
\hline 肺線維症 & 0 & 1 & 1 & 口腔内再発腫瘍からの大量出血 & 1 & 0 & 1 \\
\hline 続発性肺線維症 & 1 & 0 & 1 & 喉頭浮腫 & 1 & 0 & 1 \\
\hline 器質化肺炎 & 2 & 1 & 3 & 喉頭および腎膿瘍 & 1 & 0 & 1 \\
\hline 誤嚥性肺炎 & 8 & 2 & 10 & 胃潰瘍 & 1 & 0 & 1 \\
\hline 放射線肺炎 & 3 & 0 & 3 & 出血性十二指腸潰瘍 & 1 & 0 & 1 \\
\hline 肺出血 & 1 & 2 & 3 & 直腸潰瘍（直腸腟瘻形成） & 0 & 1 & 1 \\
\hline 気管出血＋食道気管瘻 & 1 & 0 & 1 & 穿孔性結腸潰瘍 & 0 & 1 & 1 \\
\hline 気管支出血 & 1 & 1 & 2 & 癌性䯣膜炎 & 1 & 1 & 2 \\
\hline 肺鬱血（水腫） & 1 & 2 & 3 & 脳出血 & 3 & 0 & 3 \\
\hline 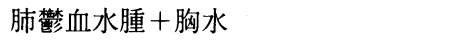 & 1 & 0 & 1 & 脳浮腫 & 1 & 1 & 2 \\
\hline 肺栕血＋出血 & 1 & 0 & 1 & 心臓弁膜症 & 1 & 0 & 1 \\
\hline 肺水腫 & 3 & 0 & 3 & 心不全 & 1 & 0 & 1 \\
\hline 肺虚脱 & 0 & 1 & 1 & 心肥大+冠不全 & 1 & 0 & 1 \\
\hline 右無気肺 & 1 & 0 & 1 & 心筋梗塞 & 1 & 0 & 1 \\
\hline 胸水 $(900,1200: 1000,1500 \mathrm{ml})$ & 1 & 1 & 2 & 結核症（肺） & 1 & 0 & 1 \\
\hline 彌漫性肺胞障害 & 0 & 1 & 1 & 全身播種性結核 & 0 & 1 & 1 \\
\hline 腫瘍による気管支狭窄，閉塞 & 1 & 1 & 2 & 急性出血（癌性潰瘍） & 1 & 0 & 1 \\
\hline 気管気管支内血液，喀痰充満 & 1 & 1 & 2 & 肝門部瘉着性閉塞性黄疸 & 1 & 0 & 1 \\
\hline 左右気管支内異物 & 1 & 0 & 1 & 化膿性腹膜炎 & 0 & 1 & 1 \\
\hline 凝血塊誤嚥 & 0 & 1 & 1 & ショック腎 & 1 & 0 & 1 \\
\hline 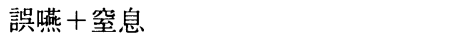 & 0 & 1 & 1 & 硬化性系球体腎炎 & 1 & 0 & 1 \\
\hline 血液誤嬹＋肺㨏血水腫 & 1 & 0 & 1 & 高Ca血症に伴うCa沈着 & 1 & 0 & 1 \\
\hline
\end{tabular}

“輯報の記載をそのまま集計 
表12 舌癌剖検症例の出所別平均年齢

\begin{tabular}{|c|c|c|c|c|c|}
\hline \multirow{2}{*}{ 出 所 } & \multicolumn{5}{|c|}{ 年 度 (症例数*) } \\
\hline & 1987 & 1988 & 1989 & 1990 & 1991 \\
\hline 耳鼻科 & $63.4 \pm 11.2(22)$ & $61.2 \pm 12.7(29)$ & $61.8 \pm 14.0(20)$ & $64.7 \pm 9.8(21)$ & $62.4 \pm 11.2(23)$ \\
\hline 口腔外科 & $60.7 \pm 13.3(25)$ & $64.3 \pm 12.2(19)$ & $57.2 \pm 12.8(23)$ & $57.2 \pm 14.5$ & $63.9 \pm 12.6$ \\
\hline & $60.1 \pm 15.7(9)$ & $68.8 \pm 9.0(15)$ & $69.4 \pm 16.2(14)$ & $65.3 \pm 11.2(10)$ & $67.1 \pm 12.9$ \\
\hline 放射線科 & $67.0 \pm 15.7(10)$ & $62.2 \pm 15.9(5)$ & $50.4 \pm 21.7(5)$ & $73.8 \pm 8.2(6)$ & $60.7 \pm 12.7(3)$ \\
\hline 頭 頸 科 & $62.0 \pm 9.7(4)$ & $69.2 \pm 7.4(6)$ & $63.3 \pm 11.9(7)$ & $63.9 \pm 14.8(8)$ & $62.2 \pm 7.5(5)$ \\
\hline 科 & $67.5 \pm 9.2(2)$ & $68.6 \pm 10.1(5)$ & $57.0(1)$ & $(0)$ & $58.5 \pm 10.6(2)$ \\
\hline
\end{tabular}

*多重癌症例は除き扁平上皮癌のみ集計，兼科は 2 例とした

表13 舌癌剖検症例の出所別に見た多重癌症例数の割合

\begin{tabular}{ccccccc}
\hline \multirow{2}{*}{ 出 所 } & \multicolumn{5}{c}{ 多重癌症例数 /剖検症例数 } \\
\cline { 2 - 7 } & 1987 & 1988 & 1989 & 1990 & 1991 & 合計 (\%) \\
\hline 耳 劓 科 & $2 / 24$ & $4 / 33$ & $7 / 27$ & $3 / 24$ & $1 / 24$ & $17 / 132(12.9)$ \\
口腔外科 & $3 / 28$ & $5 / 22$ & $4 / 27$ & $3 / 16$ & $1 / 18$ & $16 / 111(14.4)$ \\
内 科 & $5 / 14$ & $7 / 23$ & $10 / 25$ & $13 / 22$ & $7 / 21$ & $42 / 105(40.0)$ \\
放射線科 & $2 / 12$ & $3 / 8$ & $0 / 6$ & $5 / 11$ & $3 / 6$ & $13 / 43(30.2)$ \\
頭 頸 科 & $0 / 4$ & $3 / 7$ & $3 / 10$ & $2 / 10$ & $3 / 8$ & $11 / 39(28.2)$ \\
外 科 & $5 / 7$ & $2 / 7$ & $1 / 1$ & $3 / 3$ & $3 / 5$ & $14 / 24(58.3)$ \\
\hline 合 計 & $17 / 89$ & $24 / 100$ & $25 / 97$ & $29 / 86$ & $18 / 82$ & $113 / 454$ \\
(\%) & $(19.1)$ & $(24.0)$ & $(25.8)$ & $(33.7)$ & $(22.0)$ & $(24.9)$ \\
\hline
\end{tabular}

兼科の症例は 2 例とした

最も多いのは 1990 年の 30 例（33.3\%）であった. 性別 にみた多重癌症例数の割合では男性（28.5\%）が女性 症例 $(19.9 \%)$ よりも高かったが, 男女間に有意の差 ( $\mathrm{X}^{2}$ テスト) は認められなかった.

二重癌症例は 99 例であったが (表 7 ), 舌の悪性新 生物と重複する臓器では肺 (20 例), 胃 (19 例), 食道 （15例）などが比較的多く, 次いで前立腺, 甲状腺, 大 腸, 歯肉, 肝臓などと重複する症例が多かった。三重 癌症例は 22 例あったが (表 8 ), 食道と肺, 肺と胃な どと重複する拝例がおのおの 2 例であり, 他の臟器と 重複する症例は 1 例づつであった。四重癌は 2 例であっ た(表 8 ).

舌単独癌症例の平均年齢（症例数）は 1987 年, 1988 年, 1989 年, 1990 年, 1991 年について, それぞれ 62.4 \pm 13.3 歳 (73), $63.7 \pm 12.4$ 歳 (76), 61.5 \pm 15.2 歳 (74), $64.2 \pm 12.8$ 歳 (60), $64.0 \pm 12.2$ 歳 (67) で, 多重癌症例 の年齢はそれぞれの年度について, $68.0 \pm 8.9$ 歳 (19), $67.4 \pm 10.9$ 歳 (29), 64.8 10.4 歳 $(26), 66.1 \pm 11.4$ 歳 (30), $66.0 \pm 10.8$ 歳 $(20)$ であり, いずれの年度におい
ても多重癌症例の年齢が高かった.

6. 舌癌の転移部位とその症例数 (表 9,10)

臟器転移 (表 9 ) では肺が 225 例で認められ, 次い で肝, 肝内胆管 (88 例), 骨 (87 例), 皮䖉 · 皮下組織 (76 例), 肋膜 - 胸壁 (75 例), 甲状腺 (72 例) などが 多かった。

リンパ節転移をその部位別（表 10）にみると, 頸部 (133例), 肺 ·肺門 (91例), 喉頭 - 食道 ·気管周囲 $(62$ 例）などが多い部位であった。

\section{7. 死因となった副病変 (表 11)}

死因となった副病変については輯報に記載されてい る病変をそのまま集計した（表 11）。これを基にまと めてみると, 肺の感染症が最も多く(96 例), 肺の循 環障害 (16 例), 敗血症 (15 例), 出血（血管の破綻, DIC など) (15例), 気道の狭窄・閉塞（9例）などが 比較的多かった。

\section{8 . 出所別の症例数と平均年齢（表 12）}

すべての症例を出所別にみると（兼科 4 例）, 耳鼻 科が 132 例と最も多く, 次いで口腔外科の 112 例であ 

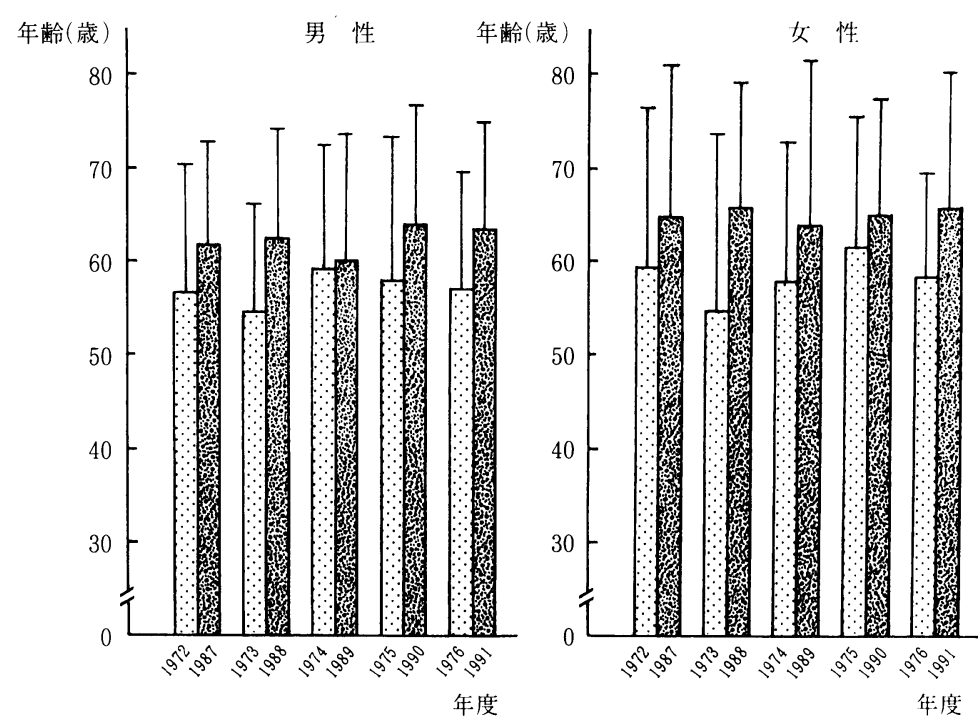

図1＼cjkstart舌癌剖検症例の死亡年齢の比較

り，内科が 105 例，放射線科が 43 例，頭頸科が 39 例, 外科が 24 例，その他・不明が 22 例となっていた。多 重癌症例を除き扁平上皮癌についてのみ集計した平均 年齢を年度別にみると, 年度ごとに多少の変動はみら れたが, 検索した 5 年間では逐年的に特別の傾㐰は明 らかでなかった。

また, 症例の出所別に多重癌症例の割合を集計して みると（表 13）, 外科および内科の症例では多重癌症 例が多く,耳鼻科や口腔外科の症例では多重癌症例の 割合は低かった。

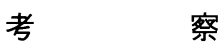

\section{1. 舌の悪性新生物による死亡者数と剖検率}

舌癌は口腔内の癌では最も一般的である $21-23)$. 1975 年にわが国の 7 施設における口腔扁平上皮癌の 集計を行った結果 (1975) では, 舌癌が最も多く, 39.3 \%であったと報告されている24). 米国 (1975-86) では 口腔内扁平上皮癌の $30.1 \%$ が舌癌であったと報告され ている22)。著者らの教室で最近 3 年間に扱った病理 組織検査では口腔扁平上皮癌 104 例のうち舌癌が 37 例 $(35.6 \%)$ で, 最も多かった24〜26).

わが国における舌の悪性新生物による死亡者数はほ ぼ逐年的に増加し1 12)（表 1)，今回の研究で対象と した 5 年間 (1987〜1991) の合計では 3269 例であった. 著者らはこれまでわが国における舌癌剖検症例数を 5 年ごとにまとめ報告してきた ${ }^{13 \sim 15)}$. 人口動態統計に よると, 舌の悪性新生物による死亡者数は 1972～1976 年 ${ }^{13)}$ が 2372 例，1977 1981 年 ${ }^{14)}$ が 2709 例，1982
1986 年 ${ }^{15)}$ が 2966 例と著しい増加がみられている。 方，それぞれの検索期間における舌墨性新生物の剖検 症例数は 253 例， 404 例，545 例と増加していた。し かし，今回検索した期間（1987-1991）における舌悪性 新生物の剖検数は 473 例であり，著しく減少していた。 これらの㱑例数を基におのおのの検索期間ごとに剖検率 を単純計算してみると, $10.7 \%{ }^{13)}, 14.9 \%{ }^{14)}, 18.4 \%{ }^{15}$ と次第に高くなってきたが, 今回の検索した最近の 5 年間では $14.5 \%$ と低減していたのは心外であった。

\section{2 . 舌癌症例の年齢とその発生部位}

1930 年から 1957 年:までの 28 年間に東京医科歯科大 学口腔外科教室を訪れた 51 例の舌原発癌についてま とめた塩山ら ${ }^{23)}$ によれば，その平均年齢は 52 歳であっ たと報告している。また，末抹ら21)は1979 年から 1992 年までに菌科放射線科を受診した舌癌患者 (113 例）の年齢を報等门しているが，それによると男性は 60.0 歳, 女性は 56.8 歳, 平均で 58.6 歳であり, 他部位 の癌患者と比較し辞浛はより低年齢で発生する傾向に あったと報告している，著者らはこれまでわれわれの 教室で扱った生検怔例を集計しているが，今回，1991 年 ${ }^{24)}, 1992$ 年 ${ }^{25)}$ および 1993 年26) の 3 年:間に取り扱っ た舌癌症例の初診時の年齢 (未発表) を検索したとこ 万, 最年少者が 43 墄（女性），最高年者は 94 歳（男性） であり，男性の平均は $60.7 \pm 12.2$ 歳（22）で，女性の 平均が $66.9 \pm 13.0$ 歳（14）であり，全体では $63.1 \pm$ 13.2 歳（36）であった。これらの㷛からみて, 近年, 㐘科外来を訪れる舌澏患者に高齢化の傾问が推察された。

著者らは本稿をまとめるにあたり，先に報告 ${ }^{13)} し$ た 1972 年から 1976 年までの各年度の舌湂剖検症例の 
平均年齢（多重癌埗例を除き孚単独癌怔例のみ）を改 めて算定しこれらと今四集計した期間の各年度の平 均年齢をそれぞれ比較した（図 1 ). その結果, この 15 年間に男性では 0.9 年から 7.9 年，女性では 3.6 年か ら 11.3 年, 舌澏剖検怔例の年:㱓が帛くなっていた。こ の要因は種々あると思われるが，患者の疾病に対する 意識のほかに臨床的には診断技術はじめ治療法の们上. などを否定し得ないものと理解した。

\section{3 . 多重癌症例と重複臟器}

これまでに著者らが報告した舌癌剖検为例では 253 例中に 18 例 $(7.1 \%)^{13)}$ ，404 例中に 65 例 $(16.1 \%)^{14)}$, 545 例中に 117 例 $(21.5 \%)^{15)}$ の多重癌将例がみられ ている。今回集計した期間についてみれば多重癌症例 が 123 例 (26.0\%) 認められ，而の悪性新生物剖検怔 例における多重癌症例数の割合が検索期間ごとに高く なってきていた。これは死し年龄がトがるにしたがい, 他臓器に新生物が新たに発牛する叮能性を小唆する所

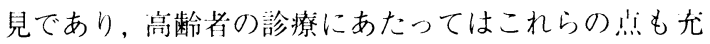
分に考虑しなければならないと考えられた。

舌の悪性新生物と重複して発特する腫陽は食道, 胃, 肺などに多い13-15) が, 今吤の集計でもこれらの臓器 と重複する政例が多かった。

今回, 多重癌症例の割合を剖検症例の出所别にみた が, 訬療科によりこの割合が大きく異なっていた。こ の要因の明確な解明はできなかったが, 今後も怔例を 増すなどして検討し，この蚛の解明も進めなければな らない.

\section{4. 舌癌の転移と死因となった副病変}

舌癌剖検怔例の臓器転移について系統的にまとめた 報告は少ない，著者らがこれまでに票癌剖検症例につ いて集計した成績 ${ }^{13}$-15)では肺，呐頭，甲状腺，心，肺， 腎，皮䖉などに転移する班例が多く，中状腺や副腎な ども小さな臓器ではあるが転移していた泟例が比較的 日立った。また, 䫓蓋省, 下顎省のほかに椎骨, 肋骨 に軽移している拝例が多いと報算したが13-15)，今回 の集計でもこれまでに多いとされていた蔵器に転移し ている怔例が多かった。リンパ節転移では頸部, 肺門, 傍気管, 鎖简卜窩, 縦隔, 傍大動脈などへ転移してい る班例が多かったが13-15)，今沁の集胡でもこれらの 部のリンパ節へ転移している怔例が多く, 従米の報告 と特別の違いはみられなかった。

死因となった副病変では肺の感染班が最も多く，気 道の閉塞や出血による班例も比較的多くなっていた。 これらの死因となった副㖞変はこれまでに集計した舌 癌剖検症例でも多いとされていたものであり13-15), 今回の集計では特別に変わった!帒はみられなかった。

結

わが国において過去 5 柋:間（1987-1991）に剖検され
た舌の悪性新生物症例を口本病理剖検輯報から収集し， 種々の観!们ら検討した。

その結果以下の結論を得た。

1. 舌の悪性新生物剖検症例数は 473 例（男 337 例, 女 136 例)であった。

2.わが国の舌の悪性新生物による死亡者数に対す る剖検率は $14.5 \%$ であった。

3 . 年代別では 60 歳代が最も多く, 次いで 70 歳代, 50 歳代となり，これらの年代の症例を合わせると全体 の $75.3 \%$ であた.

4.この 5 年間で平均年齢に逐年的な特別の傾向は みられなかったが，15年前の剖検症例に比較して平均 年齢が男性で $0.9 \sim 7.9$ 年, 女性で $3.6 \sim 11.3$ 年高くなっ ていた。

5. 組織型別には $96.6 \%$ が扁平上皮癌であった。

6 . 扁平上皮癌の発生部位では舌（側）縁部が 53.5 $\%$, 次いで舌根 (後) 部が $28.9 \%$ でった.

7. 臓器転移では肺, 朋, 骨, 皮䖉 - 皮下組織, 肋 膜・胸膜, 甲状腺などに多く, リンパ節では頸部, 肺 ・ 肺門，喉頭・食道・気管周囲などに多かった。

8. 多重癌症例は舌単独癌症例よりも平均年齢が高 かった，症例を出所別にみると, 多重癌は外科, 内科 の泟例に多く,耳鼻科，口腔外科の怔例には少なかっ た。

9. 死因となった副病変では肺の感染症が最も多かっ た。

本論文の要旨は岩手医科大学菌学会第 32 回例会 (1991, 6, 29, 盛岡市), 同第 17 回総会 $(1991,11,16$, 盛岡市), 同第 34 回例会 $(1992 ， 6 ， 27$, 盛岡市), 同第 37 回例会 (1994，11，19，盛岡市)，第 39 回日本口腔外科学会総会 （1994，11，7，名古屋市）において発表した。

\section{引用 文 献}

1）厚生省大臣官房統計情報部編：昭和 56 年度人 口動態統計。下巻, 財団法人厚生統計協会, 東 京, 1983, 94-95 頁.

2）厚生省大臣官房統計情報部編：昭和 57 年度人 口動態統計.下巻, 財団法人厚生統計協会, 東 京, 1984, 94-95 頁.

3）厚生省大臣官房統計情報部編：昭和 58 年度人 口動態統計. 下巻, 厚生省大臣官房統計情報部, 東京, 1985, 94-95 頁.

4）厚生省大臣官房統計情報部編：昭和 59 年度人 口動態統計。下巻, 財団法人厚生統計協会, 東 京, 1986, 94-95 頁.

5）厚生省大臣官房統計情報部編：昭和 60 年度人 口動態統計. 下巻, 財団法人厚生統計協会, 東 京, 1987, 94-95 頁.

6）厚生省大臣官房統計情報部編：昭和 61 年度人 口動態統計. 下巻, 財団法人厚生統計協会, 東 
京, 1988, 94-95 頁.

7）厚生省大臣官房統計情報部編：昭和 62 年度人 口動態統計. 下巻, 財団法人厚生統計協会, 東 京, 1989, 94-95 頁.

8）厚生省大臣官房統計情報部編：昭和 63 年度人 口動態統計. 下巻, 財団法人厚生統計協会, 東 京, 1990, 94-95 頁.

9）厚生省大臣官房統計情報部編：平成元年度人口 動態統計. 下巻, 財団法人厚生統計協会, 東京, 1991, 94-95 頁.

10）厚生省大臣官房統計情報部編 : 平成 2 年度人口 動態統計. 下巻, 財団法人厚生統計協会, 東京, 1992, 94-95 頁.

11）厚生省大臣官房統計情報部編 : 平成 3 年度人口 動態統計. 下巻, 財団法人厚生統計協会, 東京, 1993, 94-95 頁.

12）厚生省大臣官房統計情報部編：平成 4 年度人口 動態統計. 下巻, 財団法人厚生統計協会, 東京, 1994, 94-95 頁.

13）佐藤方信, 佐島三重子, 他：日本病理剖検輯報 に基づく舌癌剖検症例の検討, 口科誌 29: 37-43 1980 .

14）佐藤方信, 畠山節子, 他：日本病理剖検輯報に 基づく舌癌剖検症例の統計的検討, 日口外誌 34: 157-163 1988.

15）佐藤方信, 佐島三重子, 他：日本病理剖検輯報 に基づく舌癌剖検症例の統計的検討（第 III 報）， 日口外誌 34: 2576-2585 1988.

16）日本病理学会編：日本病理剖検輯報. 第 30 輯, 日本病理剖検輯報刊行会, 東京, 1989, 1 -1418 頁.

17）日本病理学会編：日本病理剖検輯報. 第 31 輯,
日本病理剖検輯報刊行会, 東京, 1990,1 -1410 頁.

18）日本病理学会編：日本病理剖検輯報. 第 32 輯, 日本病理剖検輯報刊行会, 東京, 1991，1-1387 頁.

19）日本病理学会編：日本病理剖検輯報. 第 33 輯, 日本病理剖検輯報刊行会, 東京, 1992, 1 -1383 頁.

20）日本病理学会編：日本病理剖検輯報. 第 34 輯, 日本病理剖検輯報刊行会, 東京, 1993, 1 -1325 頁.

21）末井良和, 谷本啓二, 他 : 口腔領域扁平上皮癌 の統計的観察, 口科誌 42: 757-761, 1993.

22) Krushkoff, D. J., Chen J. et al.: Oral cancer: A survey of 566 cases from the university of Connecticut Oral Pathology Biopsy Service 1975-1986, Oral Surg, Oral Med, Oral Pathol 70: 192-198, 1990.

23）塩田重利, 清水正嗣, 他 : 舌癌の臨床統計的観 察, 口外会誌 $4: 62-66,1958$.

24）佐藤方信, 佐藤泰生, 他 : 本学歯学部口腔病理 学教室における病理組織検査の報告 -1991 年 度の集計一, 岩医大歯誌 18: 136-142, 1993.

25）佐藤方信, 藤井佳人, 他 : 本学歯学部口腔病理 学教室における病理組織検査の報告－1992 年 度の集計一, 岩医大歯誌 18: 210-215, 1993.

26）佐藤方信, 藤井佳人, 他 : 本学歯学部口腔病理 学教室における病理組織検査の報告－1993 年 度の集計一, 岩医大歯誌 20: 93-97, 1994.

27）塩田重利, 天笠光雄 : 口腔覀性腫瘍治療の現状一 とくに舌癌を中心にー, 医学のあゆみ 134: 955 961, 1985. 